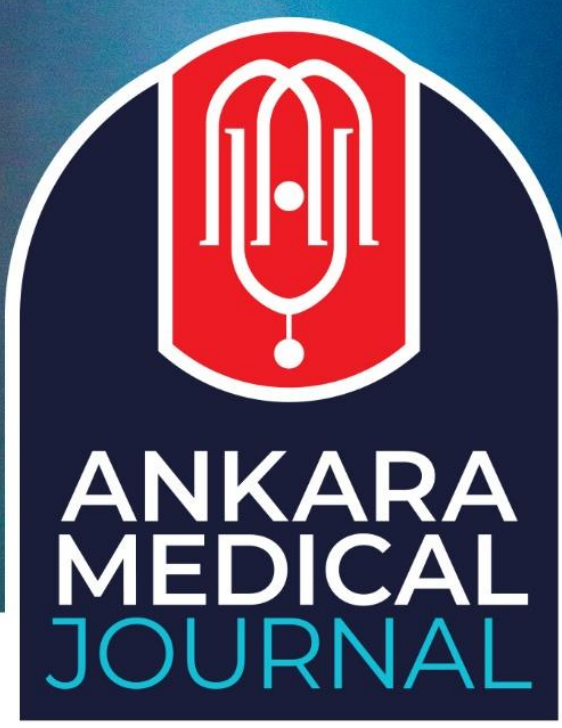

Research Article

Ankara Med J, 2020;(1):47-56 // (6i) 10.5505/amj.2020.71542

\title{
EVALUATION OF THIOL DISULPHIDE HOMEOSTASIS AND NEUTROPHILE LYMPHOCYTE RATIO IN CARBON MONOXIDE INTOXICATION
} KARBONMONOKSITT ZEHİRLENMESİNDE THİOL DİSULFİ HOMEOSTAZISII VE NÖTROFIL LENFOSITT ORANI DEĞERLENDİRİLMESİ

(D) Fatih Tanrıverdi1, (D) Yücel Yüzbaşığlu², (D) Fadime Güllü Ercan Haydar3,

(D) Servan Gökhan1, (D) Ayhan Özhasenekler1, (D) Çağdaş Yıldırım¹,

(D) Fatih Ahmet Kahraman', (D) Funda Eren ${ }^{4}$

${ }^{1}$ Ankara Yıldırım Beyazıt University, Faculty of Medicine, Department of Emergency Medicine,

\section{Ankara}

${ }^{2}$ Keçiören Training and Research Hospital, Department of Emergency Medicine, Ankara

${ }^{3}$ Ankara City Hospital, Department of General Surgery, Ankara

${ }^{4}$ Ankara City Hospital, Department of Biochemistry, Ankara

Yazışma Adresi / Correspondence:

Fatih Tanrıverdi (e-posta: fatihtanriverdi12@gmail.com)

Geliş Tarihi (Submitted): 23.01.2020 // Kabul Tarihi (Accepted): 18.02.2020

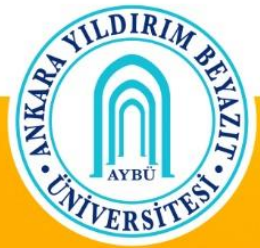

Ankara YIldırım Beyazıt University Faculty of Medicine 


\title{
Öz
}

Amaç: Bu çalışmanın amacı acil servise karbon monoksit zehirlenmesi nedeniyle başvuran hastalarda oksidatif stres markerlarından olan thiol/disülfit homeostazis parametreleri ile Nötrofil-Lenfosit (NLO) beraber kullanımının tanı açısından yararlı olup olmadığını araștırmaktır.

Materyal ve Metot: Çalıșma 01.01.2014 ile 01.03.2015 tarihleri arasında acil servise başvuran ve çalışmaya alınan 45 hasta ve kontrol grubu olarak belirlenen 40 sağlıklı kişi ile prospektif olarak yapıldı. Erel ve Neșelioğlu tarafından yeni geliştirilen bir metot ile oksidatif stres markerı olan thiol/disülfit homeostazis parametreleri (Thiol, disülfit, disülfit/native thiol, disülfit/total thiol, native thiol/total thiol) ile NLO hasta ve kontrol grubunda çalışıldı.

Bulgular: Karbonmonoksit zehirlenmesi olanlarda kontrol grubuna göre, NT, TT, index 3 ve NLO oranlarında anlamlı farklılık tespit edildi. NT, TT ve index 3 hasta grubunda daha düşük, NLO ortalama değerleri daha yüksek bulundu (sırasiyla $\mathrm{p}=0,005 ;<0,001 ;<0,032$ ve $<0,001$ ).

Sonuç: NLO ile thiol/disülfit homeostasis parametrelerinin karbonmonoksit zehirlenmesi tanısında beraber kullanılması bu hastalarda tanının konulması açısından faydalıdır.

Anahtar Kelimeler: Karbonmonoksit zehirlenmesi, NLO, thiol/disülfit homeostasis

\begin{abstract}
Objectives: The aim of this study is to search if using thiol/disulphide homeostasis together with Neutrophile Lymphocyte Ratio (NLR) which are oxidative stress markers in patients who apply to the emergency service with carbon monoxide intoxication is useful regarding diagnosis or not.

Materials and Methods: The study was performed prospectively with 45 patients who applied to the emergency service between 01.01.2014 - 01.03.2015 and who were included in the study and 40 healthy persons who were determined as control group. Thiol/disulphide homeostasis parameters (Thiol, disulphide, disulphide / native thiol, disulphide / total thiol, native thiol / total thiol) and NLR which are oxidative stress markers were studied in the patient and control groups by a method which was developed newly by Erel and Neşelioğlu.

Results: In persons with carbon monoxide intoxication, a significant difference was detected in NT, TT, index 3 and NLR rates according to the control group. NT, TT and index 3 were found lower in the patient group, and NLR mean values were found higher in the patient group ( $p=0.005,<0.001,=0.032,<0.001$ respectively).

Conclusion: To use NLR together with thiol/disulphide homeostasis parameters in the diagnosis of carbon monoxide intoxication is useful regarding diagnosing in these patients.

Keywords: Carbon monoxide intoxication, NLR, thiol/disulphide homeostasis.
\end{abstract}




\section{Introduction}

Carbon monoxide (CO) intoxication is the reason of more than 50\% intoxications all around the world which results in injury or death. ${ }^{1}$ Recognizing $\mathrm{CO}$ intoxication is difficult due to its nonspecific signs and symptoms; it is thought that, true morbidity and mortality rates are higher due to diagnosis of $\mathrm{CO}$ intoxication is difficult. ${ }^{1-2}$ CO intoxication is called "silent killer" due to its characteristics which are odor-free, colorless and non-irritant. ${ }^{3}$ While carboxyhemoglobin ( $\mathrm{COHb}$ ) level may be between 3-8\% in continuous smokers, this level may be as high as $10 \%$ in heavy smokers, drivers who work at heavy traffic and furnace stokers. ${ }^{4,5}$

Mechanisms of CO intoxication depend on hemoproteins, cytochrome oxidase and cytochrome p450 systems. ${ }^{5} \mathrm{COHb}$ formation results in tissue hypoxia and ischemia. Impaired perfusion and $\mathrm{CO}$ related tissue damage increase the effect of $\mathrm{CO}$ intoxication. ${ }^{6}$ Inhibition of mitochondrial enzymes cause lipid peroxidation in membranes. ${ }^{6}$ Besides $\mathrm{CO}$ binds hemoproteins of thrombocytes and induces nitric oxide (NO) release. Improved NO produces peroxynitrites and nitrogen causes stress. ${ }^{5}$

Reactive oxygen varieties are produced by electron transport chain and oxygen production increases by electron transport in normal oxidative metabolism. ${ }^{7}$ Thiols are the most important tampons which interact with nearly all physiological oxidants. ${ }^{8}$

Up to the present thiol-disulphide balance was measured only uni-directionally. However, by using the latest test methods both sides of the balance can be detected and thiol-disulphide homeostasis (TDH) can be evaluated completely. ${ }^{9}$

Neutrophile lymphocyte ratio (NLR) is cheap and obtained easily. It is a strong inflammatory response marker. NLR has been studied in many clinical conditions from infections to chronic diseases and it is an indicator which is used as a marker for systemic inflammations and infections. ${ }^{10,11}$

The main aim of this study is to show if using thiol/disulphide homeostasis parameters together with NLR is helpful regarding diagnosis or not in the patients who admit to the emergency service with CO intoxication.

\section{Materials and Methods}

45 patients and 40 healthy volunteers in a total of 85 subjects were included in this open prospective crosssectional and diagnostic study. The study has been made at Ankara Atatürk Training and Research Hospital emergency service and approval was received previously from Yildırım Beyazit University Medical Faculty Ethics Committee (03/12/2014-214). Informed consent form has been obtained from all patients. Patients 
above 18 years of age who applied to the emergency service and who were diagnosed with CO have been included in the study. Pregnant women, patients who didn't accept to take part in the study, active and infection, chronic inflammatory conditions (collagen tissue diseases, ischemic heart diseases, malignancies, etc, immuno-compromised patients were excluded from the study. The control group consisted of persons who admitted to our emergency department during the same period with a COHb level of less than 5\% and who had no disease. Study group out of patients whose venous blood gas samples showed 10\% and above COHb levels was established as carbon monoxide poisoning.

Blood samples were taken within the first hour of application to the emergency service before starting any medicine. Parameters which are used to evaluate THD have been measured in an automatic analyzer by a novel spectrophotometric method which was developed by Erel and Neșelioğlu. ${ }^{8}$ Levels of native thiol (NT), total thiol (TT) and disulphide (D) have been measured by this method and then the ratios of these 3 parameters were calculated (Index 1: D/NT, index 2: D/TT, index 3: NT/TT).

Reciprocal analysis of blood gas parameters against oxidative stress parameters was made in the patient group. Also, biochemical parameters were compared with thiol/disulphide analysis results.

\section{Statistical analysis}

SPSS 16.0 for Windows package software (IBM Corp.; Armonk, NY, USA) was used for statistical analysis in the study. Normality analysis was made by Kolmogorov Smirnov Test. Data that show normal distribution was described as mean \pm standard deviation and data which don't show normal distribution was described as median and min-max. In the comparison of two independent groups, Mann Whitney-U test was used for parameters that didn't show normal distribution and the Independent Samples t-test was used for parameters that showed normal distribution. Spearman correlation test was used for correlation of biochemical parameters, Pearson test was used for data which showed normal distribution. Receiver Operating Characteristics (ROC) analysis was used for the value of oxidative stress parameters in estimating illness; area under the curve, sensitivity, specificity were calculated. $\mathrm{p}<0.05$ was used for statistical significance level.

\section{Sample Size}

In the literature, there is no previous study which evaluates the relation between thiol/disulphide homeostasis parameters and NLR in CO patients. However, it was seen that there were $14-18 \%$ and $15-18 \%$ decrease respectively in native thiol and total thiol levels according to the control group in the studies which were made by the same method about thiol/disulphide homeostasis in patient groups with ischemic stroke, lung cancer, and pulmonary embolism. ${ }^{12-13}$ By regarding data of healthy volunteer control group in the study of Bektaş et al., when accepting 80\% strength and 5\% Type-1 error, it was calculated that 16 individuals should be taken to 
each group in order to show that $10 \%$ decrease is significant. In the same way, it was calculated that 14 individuals should be taken to each group for TT.

\section{Results}

45 patients who had CO intoxication diagnosis and 40 healthy volunteers were included in the study. No statistically significant difference was detected regarding gender and age distributions of the groups (Table 1).

Comparison was made between two groups regarding NT, TT, D and index 3 , there was a statistically significant difference in NT, TT, index 3 and NLR values (Table 2). NT, TT, and index 3 values were lower and NLR value was higher in the patient group.

ROC analysis, sensitivity, specificity and area under the curve for NLR are presented below (Figure 1 and Table $3)$.

Table 1. Demographic features of groups

\begin{tabular}{|l|c|c|c|}
\hline Demographics & Control (n=40) & CO (n=45) & p \\
\hline Age-median (min-max) & $45(19-75)$ & $50(17-83)$ & 0.457 \\
\hline Gender (female/male ) & $15 / 25(37.50 / 62.50 \%)$ & $15 / 29(33.30 / 66,70 \%)$ & 0.853 \\
\hline
\end{tabular}

CO: Carbon Monoxide intoxication

Table 2. Thiol/disulphide homeostasis parameters (patient vs. control group)

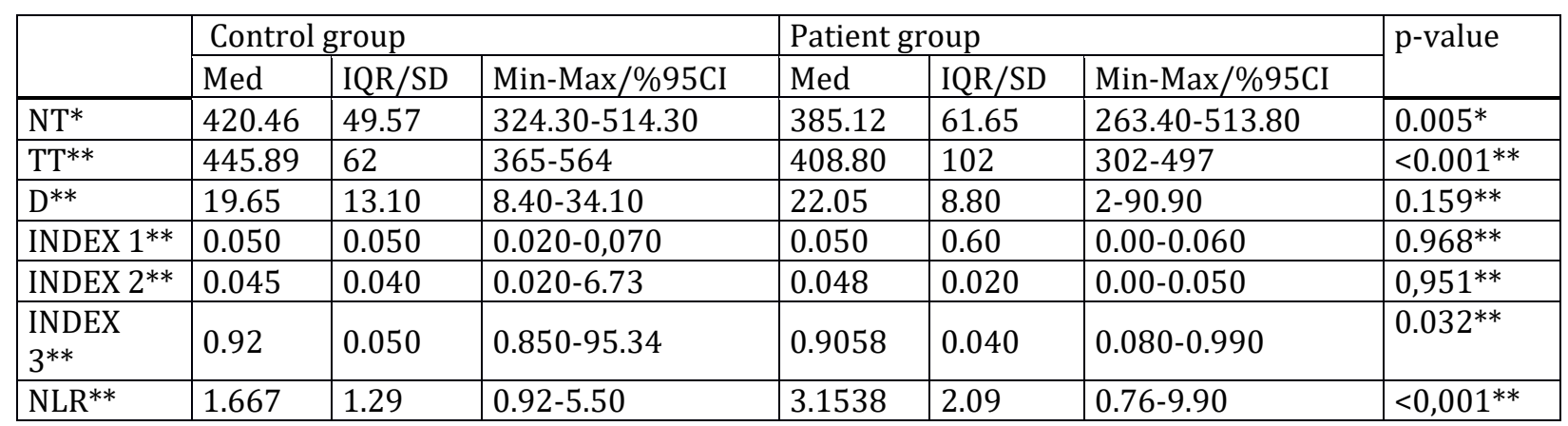

*Independent Samples t-test (mean); SD (standard deviation); 95\% CI (confidence interval)

**Mann Whitney-U test; IQR: interquartile range; med: median, NT : Native Thiol, TT :total thiol D :disulphide NLR: Neutrophile Lymphocyte Ratio 


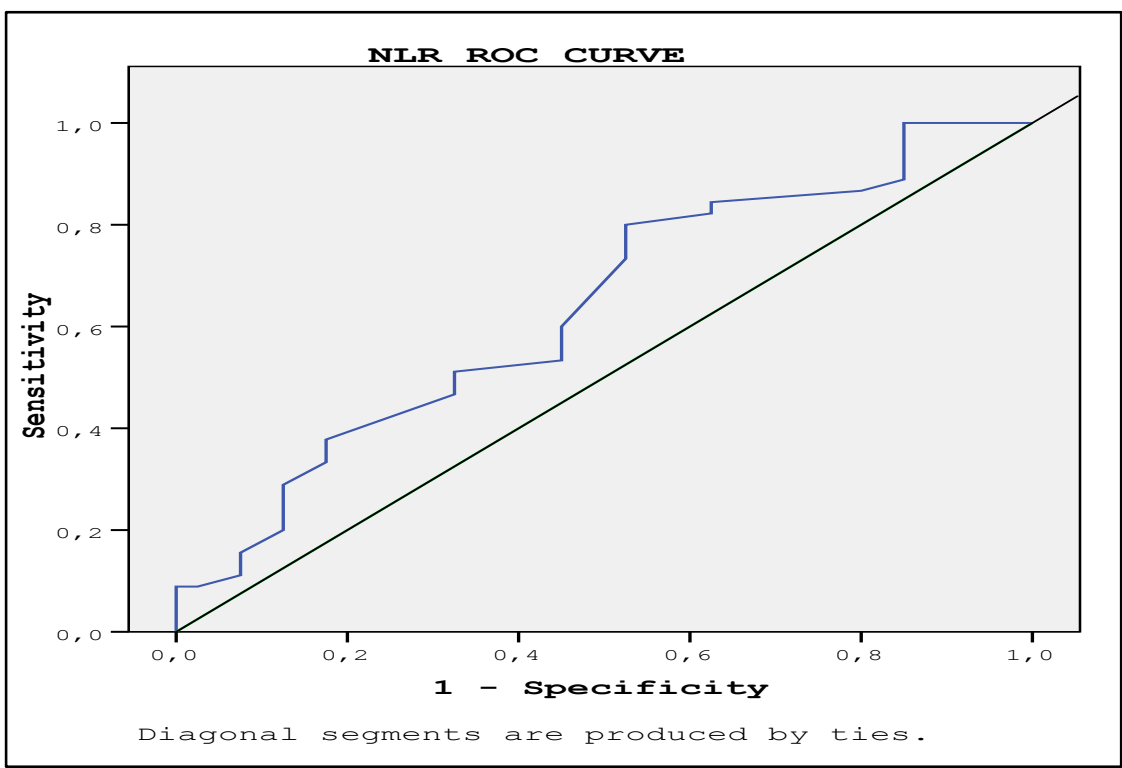

Figure 1. ROC analysis and area under the curve for NLR (diagnostic evaluation of CO)

Table 3. ROC analysis

\begin{tabular}{|c|c|c|c|c|}
\hline \multirow{2}{*}{ Variable(s) } & \multirow{2}{*}{$\begin{array}{c}\text { Area under curve } \\
(\text { Null hypothesis: true area }=0.5)\end{array}$} & \multirow{2}{*}{ p-value } & \multicolumn{2}{|c|}{ 95\% Confidence Interval } \\
\hline & & & Lower Bound & Upper Bound \\
\hline NT & 0.652 & $\mathrm{P}=0.16$ & 0.536 & 0.769 \\
\hline TT & 0.734 & $\mathrm{p}<0.001$ & 0.628 & 0.840 \\
\hline INDEX 3 & 0.635 & $\mathrm{P}=0.032$ & 0.517 & 0.753 \\
\hline NLR & 0.785 & $\mathrm{p}<0.001$ & 0.686 & 0.885 \\
\hline \multicolumn{5}{|c|}{ Cut-off values for NLR (diagnostic evaluation for CO) } \\
\hline Variable(s) & & Cut-off & Sensitivity-\% & Specificity-\% \\
\hline \multirow{3}{*}{ NLR } & & 2.3560 & 73.30 & 72.50 \\
\hline & & 2.4207 & 73.30 & 75 \\
\hline & & 2.4618 & 71.10 & 75 \\
\hline
\end{tabular}

NT : Native Thiol , TT :total thiol D :disulphide NLR: Neutrophile Lymphocyte Ratio CO:Carboxyhemoglobin 
Table 4. Correlation of biochemical and thiol/disulphide parameters

\begin{tabular}{|c|c|c|c|c|c|c|c|}
\hline $\begin{array}{l}\text { Spearman } \\
\text { correlation test }\end{array}$ & & NT & TT & D & Lactate & pH & $\mathrm{COHb}$ \\
\hline \multirow{2}{*}{ TT } & rho & 0.733 & & & & & \\
\hline & $\mathbf{p}$ & 0.000 & & & & & \\
\hline \multirow{2}{*}{ D } & rho & -0.145 & -0.007 & & & & \\
\hline & $\mathbf{p}$ & 0.186 & 0.952 & & & & \\
\hline \multirow{2}{*}{ Lactate } & rho & -0.411 & -0.444 & 0.076 & & & \\
\hline & p & 0.005 & 0.002 & 0.622 & & & \\
\hline \multirow{2}{*}{ pH } & rho & 0.070 & -0.023 & 0.066 & -0.110 & & \\
\hline & p & 0.647 & 0.882 & 0.668 & 0.472 & & \\
\hline \multirow{2}{*}{$\mathrm{COHb}$} & rho & -0.356 & -0.145 & -0.062 & 0.574 & -0.176 & \\
\hline & p & 0.016 & 0.344 & 0.684 & 0.000 & 0.248 & \\
\hline \multirow{2}{*}{ NLR } & rho & -0.070 & -0.154 & 0.066 & -0.065 & -0.038 & 0.073 \\
\hline & $\mathbf{p}$ & 0.524 & 0.159 & 0.549 & 0.671 & 0.804 & 0.632 \\
\hline
\end{tabular}

NT:Native Thiol, TT:total thiol D:disulphide NLR: Neutrophile Lymphocyte Ratio COHb: Carboxyhemoglobin

\section{Discussion}

The underlying mechanism for CO intoxication is not clear and the pathology of CO intoxication is quite complex. ${ }^{6}$ There is only one research that evaluates the role of thiol-disulphide homeostasis in acute CO intoxication in the study of Engin et al. ${ }^{14}$ Excessive disulphide levels were found in patients with carbon monoxide intoxication. Especially disulphide/native thiol ratio has been described as an indicator for the general oxidative condition. It was found that thiol-disulphide balance was impaired in patients with carbon monoxide intoxication. Because of that impaired thiol-disulphide homeostasis may include in CO intoxication pathology. ${ }^{14}$ In our study, NT and TT levels were statistically significantly lower in patients with CO intoxication as shown in Table 2 and D concentrations were higher according to healthy control groups, but it was not statistically significant. There were no statistically significant difference disulphide/native thiol (index 1) ratios. Native thiol/total thiol (index 3) was significantly higher in the patient group. Thiol/disulphide homeostasis plays a role in signal transmission, regulation of enzyme activities, detoxification, and apoptosis. Impairment in thiol/disulphide balance plays a role in the formation of many diseases that progress with inflammation (cardiovascular diseases, diabetes mellitus, chronic kidney failure, Alzheimer's and Parkinson and cancer). ${ }^{15,16}$ Thus it may be thought that oxidative stress is one of the most important factors in CO intoxication. ${ }^{6}$

In the study which was made by Günaydın et al., the relation between NLR and clinic findings and intensity of cardiac and neurologic complications in $\mathrm{CO}$ intoxication cases were evaluated. No significant relation was found between them. But NLR value was not compared with the control group in the study. No significant relation 
was found between NLR and COHB, troponin and GCS values. ${ }^{17}$ In our study, the NLR value was significantly higher in the patient group in comparison with the control group. In ROC analysis it can be interpreted that when NLR value is over 2.4207 the case is CO intoxication with the ratio of $73.30 \%$ and when NLR value is under that value it can be interpreted that the case is not CO intoxication in the ratio of 75,00 \%. No significant correlation relation was found between NLR value and native thiol, total thiol, lactate, ph, and COHb values.

In the study of Zengin et al. in order to examine CO intoxication antioxidant levels as compared to the study group with a healthy control group. ${ }^{18}$ These researchers have detected that TAR, PON, ARES and thiol results decreased, that is to say, antioxidant condition decreased in patients with CO intoxication. In our study, native and total thiol levels which were indicators of antioxidants, decreased, disulphide which was an indicator of oxidation increased. But even if there was an increase in disulphide, no statistically significant difference was detected.

In the study which was made by Türkdoğan et al., NLR value was found higher in the group with CO intoxication in comparison with healthy volunteers (respectively $3.01 \pm 2.34 ; 2.23 \pm 1.27 ; p=0.02$ ). ${ }^{19}$ Similar results were found in our study too.

Plasma thiol pond is also one of the antioxidant mechanisms. Thiols are oxidized through oxidants and they form disulphide bridges. These bridges can come down to thiol groups again. This dynamic thiol/disulphide homeostasis has a very important role in antioxidant defending. ${ }^{9}$ Erel and Neşelioğlu have measured thiol/disulphide homeostasis by automatic colorimetric method first time in the literature and as a result, they revealed that plasma disulphide levels increased in smokers, patients with diabetes, obesity and pneumonia and they decrease in some cancer types. ${ }^{9}$ In our study, it was shown that there was a statistically significant difference between thiol/disulphide homeostasis parameters between healthy volunteer groups. While a significant decrease was detected in NT, TT and index 3 in the patients, no significant decrease was detected in index 1 and 2; but increase in D was not found significant. We think that the significant decrease in NT and TT levels is a result of an increase in oxidative load, but disulphide increase which we thought would happen by reduction of thiols occurred, but it was not in a significant degree. In our study moderate correlation was detected between them as positive with lactate and $\mathrm{COHb}$ and negative with NT and TT, no significant correlation was detected between other parameters.

In the study of Solak et al., NT and TT levels were detected as significantly lower in smokers in comparison with the control group. By means of thiol and disulphide balance, oxidative stress has a tendency to improve rapidly. In this study disulphide levels, D / NT and D / TT levels were found significantly higher in smokers in comparison with the control group. It was seen that $\mathrm{CO}$ levels of patients showed a negative correlation with NT, TT, NT/ TT and they showed a positive correlation with D / NT and D / TT levels. This shows also that 
when CO level increases, D and oxidative stress increases too. ${ }^{20}$ In our study, only a poor significant correlation between COHb level and NT value was detected.

We couldn't detect any other study in which NLR and thiol/disulphide homeostasis were researched together in CO intoxication. Our study is the first study regarding that. We think that studying thiol/disulphide homeostasis parameters and NLR in the diagnosis of CO intoxication will be useful regarding diagnosis and it may also be effective in directing the treatment and large-scale studies with larger case numbers are needed regarding this subject.

\section{Limitations}

The main limitation is that the group of patients receiving normal oxygen therapy with hyperbaric therapy cannot be established. Besides two groups could be formed as one who took hyperbaric therapy and another one who didn't take hyperbaric therapy and its availability in detecting hyperbaric indication could be searched. Insufficiency in detecting the relation between thiol/disulphide homeostasis parameters and Neutrophile-Lymphocyte (NLR) and insufficiency in detecting the method which will be chosen in the treatment of the illness are limitations of this study.

\section{Conclusion}

Oxidative stress plays an important role in CO intoxication pathogenesis. By the technique which was developed by Erel and Neșelioğlu, thiol/disulphide homeostasis could be measured quantitatively and pathogenesis was revealed. In this study oxidative stress which was formed in CO intoxication could be shown numerically by using this technique. Differences in the patient group in comparison with the control group suggest that these biomarkers may contribute to CO diagnosis.

Conflict of Interest: The authors have no conflicts of interest to declare.

Financial Disclosure: The authors declared that this study has received no financial support 


\section{References}

1. J.A. Raub, M. Mathieu-Nolf, N.B. Hampson, S.R. Thom. Carbon monoxide poisoning a public health perspective. Toxicology 2000;145(1):1-14.

2. L.Wu, R.Wang. Carbonmonoxide: endogenousproduction physiologicalfunctions, and pharmacological applications. Pharmacol. Rev. 2005;57(4):585-630. http:// dx.doi.org/10.1124/pr.57.4.3.

3. G. Lippi, G. Rastelli, T. Meschi, L. Borghi, G. Cervellin. Pathophysiology, clinics, diagnosis and treatment of heart involvement in carbon monoxide poisoning. Clin. Biochem. 2012;45(16-17):1278-85. http://dx.doi.org/10.1016/j.clinbiochem. 2012.06.004.

4. Stanley T. Omaye, Metabolic Modulation of Carbon Monoxide Toxicity. Toxicology. 2002;180(2):139-50.

5. Raub JA, Mathieu-Nolf M, Hampson NB, Thom SR. Carbon Monoxide Poisoning- A Public Health Perspective. Toxicology 2000;145(1):1-14.

6. S. Akyol, S. Erdogan, N. Idiz, S. Celik, M. Kaya, F. Ucar, S. Dane, O. Akyol. The role of reactive oxygen species and oxidative stress in carbon monoxide toxicity: an in- depth analysis. Redox Rep 2014;19(5):180-9. http://dx.doi.org/10.1179/ 1351000214Y.0000000094.

7. T. Kalogeris, Y. Bao, R.J. Korthuis. Mitochondrial reactive oxygen species: a double edged sword in ischemia/reperfusion vs preconditioning. Redox Biol 2014;(2):702-14. http://dx.doi.org/10.1016/j.redox.2014.05.006.

8. A.M.Pisoschi, A.Pop. The role of antioxidants in the chemistry of oxidative stress:a review. Eur. J. Med. Chem 2015;97: 55-74. http://dx.doi.org/10.1016/j.ejmech. 2015.04.040.

9. O.Erel, S.Neselioglu. A novel and automated assay for thiol/disulphide homeostasis. Clin. Biochem 2014;47(18):326-32 http://dx.doi.org/10.1016/j.clinbiochem. 2014.09.026.

10. Lowsby R, Gomes C,Jarman I et al. Neutrophile to lymphocyte count ratio as an early indicator of blood stream infection in the emergency department. Emerg Med J 2015;32(7):531-4

11. Bolat D, Topcu YF, Aydogdu 0 et al. Neutrophil to lymphocyte ratio as a predictor of early penile prosthesis implant infection. Int Urol Nephrol 2017;49(6):947-53.

12. Bektas H. Vural G. Gumusyayla S. Deniz O. Alisik M. Erel O. Dynamic thiol-disulphide homeostasis in acute ischemic stroke patients. Acta Neurol Belg 2016 Dec;116(4):489-94.

13. Topuz M. Kaplan M. Akkus O. Sen O. Yunsel HD. Allahverdiyev S. Erel O. Koc M. Gur M. The prognostic importance of thiol/disulphide homeostasis in patients with acute pulmonary thromboembolism. Am J Emerg Med. 2016 Dec;34(12):2315-19.

14. Ergin M, Calıskantürk M, Senat A, Akturk O, Erel O. Disulphide stress in carbon monoxide poisoning. Clin Biochem. 2016 Nov;49(16-17):1243-47. doi: 10.1016/j.clinbiochem.2016.07.019. Epub 2016 Aug 3.

15. Kundi H, Erel Ö, Balun A, Çiçekçioglu H, Cetin M, Kiziltunç E et al. Association of thiol/disulphide ratio with syntax score in patients with NSTEMI. Scand Cardiovasc J 2015;49(2):95-100 
16. Eren Y, Dirik E, Neselioglu S, Erel O. Oxidative stress and decreased thiol level in patients with migraine: cross-sectional study. Acta Neurol Belg 2015;115(49:643-9

17. Günaydın Y, Vural K, Ok M, Katırcı Y, Kocaşaban D et.al. Comparison of carbon monoxide poisonings originated from coal stove and natural gas and the evaluation of Neutrophil/Lymphocyte ratio. Dicle Tip Dergsi 2015;42(3):299-304 doi: 10.5798/diclemedj.0921.2015.03.0578

18. S. Zengin, A B, S. Karta, B. Can, M. Orkmez, A. Taskin, U. Lok, B. Gulen, C. Yildirim, S. Taysi, An assessment of antioxidant status in patients with carbon monoxide poi- soning, World J. Emerg. Med. 2014;5(2):91-5. http://dx.doi.org/10.5847/wjem. j.1920-8642.2014.02.002.

19. Karabacak M, Türkdoğan KA, Coşkun A, Akpınar O. - Detection of neutrophil-lymphocyte ratio as a serum marker associated with inflammations by acute carbon monoxide poisoning. Journal of Acute Disease October 2015;4(4):305-8. https://doi.org/10.1016/j.joad.2015.06.009

20. Solak I, Cetinkaya CD, Gederet YT, Kozanhan B, Erel O, Eryilmaz MA. Effects of smoking on thiol/disulphide homeostasis. Eur Rev Med Pharmacol Sci. 2018 Apr;22;(8):2477-82. doi: 10.26355/eurrev_201804_14842. 